\title{
Impression Management Theory
}

\author{
Merkl-Davies, Doris
}

\section{The SAGE Encyclopedia of Corporate Reputation}

\author{
DOI: \\ 10.4135/9781483376493.n140
}

Published: 01/07/2016

Peer reviewed version

Cyswllt i'r cyhoeddiad / Link to publication

Dyfyniad o'r fersiwn a gyhoeddwyd / Citation for published version (APA):

Merkl-Davies, D. (2016). Impression Management Theory. In C. E. Carroll (Ed.), The SAGE Encyclopedia of Corporate Reputation Sage. https://doi.org/10.4135/9781483376493.n140

\footnotetext{
Hawliau Cyffredinol / General rights

Copyright and moral rights for the publications made accessible in the public portal are retained by the authors and/or other copyright owners and it is a condition of accessing publications that users recognise and abide by the legal requirements associated with these rights.

- Users may download and print one copy of any publication from the public portal for the purpose of private study or research.

- You may not further distribute the material or use it for any profit-making activity or commercial gain

- You may freely distribute the URL identifying the publication in the public portal ?
}

Take down policy

If you believe that this document breaches copyright please contact us providing details, and we will remove access to the work immediately and investigate your claim. 


\section{IMPRESSION MANAGEMENT THEORY}

Impression management, also referred to as image management or perception management, entails influencing others' perceptions of a person, an object, an event, or an idea. The sociologist Erving Goffman uses the metaphor of the theater to describe impression management as the performance of self vis-à-vis an audience. This entry first discusses the concept of impression management, then examines the audiences for organizations' impression management activities and the reliance upon public communications for organizational impression management.

The concept of impression management refers to the way organizations use public communications, symbolic actions, and physical markers to influence internal or external audiences' perceptions of the organization, its performance, organizational crises, structural reorganization (e.g., mergers, privatization, demutualization), or ideas (e.g., corporate citizenship, sustainable development, ethical investment). Impression management by means of public communications entails using annual reports, corporate social responsibility (CSR) reports, or press releases to garner financial, social, and political support from an organization's constituents. Impression management by means of symbolic actions involves, for example, the adoption of executive incentive plans or voluntary social audits of overseas factories, to give the appearance of complying with social norms and rules or conforming to standards of appropriate social conduct. Impression management by means of physical markers entails the use of logos, artifacts, and office décor to portray the organization in a positive light.

Organizations engage in impression management on an everyday basis in order to establish and maintain identity, image, reputation, and legitimacy. This entails portraying the organization in a positive light by using "upbeat” words (e.g., excellent, steep rise, leader) in public communications; producing glossy CSR reports to give the appearance a socially and environmentally responsible organization; or using logos, letterheads, and signs to portray an identity, image, or reputation with positive cultural connotations (e.g., dynamic, innovative, green, world-class). However, impression management is particularly pronounced during nonroutine events that threaten organizational identity, image, reputation, or legitimacy, such as poor financial, social or environmental performance, public controversies over environmental or social issues (e.g., pollution, use of sweatshops, minimum pay), or planned organizational changes (e.g., plant closure, privatization, merger). Impression management is thus either 
reactive and aimed at maintaining or restoring organizational legitimacy, image, or reputation, or proactive and entails persuading audiences of the necessity and legitimacy of the planned changes.

\section{Audiences for Organizations’ Impression Management}

Assessments of the desirability or normative appropriateness of an organization, its structures, practices, or performance impact on the decision-making of a range of audiences, such as investors (buying and selling shares), lenders (interest rates on loans) financial analysts (analyst recommendations), and customers (customer loyalty). Organizations thus have incentives to engage in impression management in order to decrease the cost of capital, obtain cheaper credit, gain favorable analyst recommendations, or increase their sales.

Organizations influence audience perceptions directly via public communications, such as annual reports, CSR reports, and press releases, or indirectly via the media. Media agenda setting theory states that the media is an important information intermediary between organizations and their audiences. The influence of media on audience perceptions and organizational attempts to use the media to their advantage is referred to as mediatization. News articles tend to feature quotes to add human interest. Organizations exploit this genre convention in their press releases by including top management quotes that portray the organization in a positive light.

\section{Impression Management in Public Communications}

Organizations use a variety of impression management techniques in their public communications. These are dependent on the situation and impact on audience perceptions in different ways. When faced with poor financial performance, organizations may emphasize positive aspects and obfuscate negative performance aspects (reporting bias). This entails influencing the information processing of readers of corporate communications by drawing attention to positive aspects (by means of selection or emphasis) or drawing attention away from negative aspects (by means of obfuscation). Emphasis involves repeating or visually highlighting positive organizational outcomes by means of font color, size, or bold letters. Selection entails, for example, choosing a favorable performance figure, such as the sales figure for a particular product line or geographical region, rather than the total sales figure, in the discussion of financial performance and prospects. Obfuscation entails rendering a document 
difficult to read by including long words and a complex sentence structure (reading ease manipulation) or burying bad news in small print, in footnotes, or at the end of a long document.

In an accountability context organizations may provide performance explanations that attribute positive organizational outcomes (e.g., a rise in profits) to internal factors (e.g., managerial competence) and negative organizational outcomes (e.g., a decrease in sales) to external circumstances (e.g., the recession). Being accountable involves management being answerable to financial stakeholders for performance and receiving consequences in the form of rewards or sanctions (compensation and reputation). This results in management attempting to influence shareholder and lender attributions of responsibility for organizational performance.

When faced with an organizational crisis threatening legitimacy, organizations tend to provide normalizing accounts (e.g., apologies, justifications, or excuses) combined with symbolic actions to portray it as an isolated event. For example, an organization may apologize for the incident, blame key personnel, and replace them. This serves to construct a "firewall" between audience assessments of the legitimacy-threatening event and the organization as a whole. Alternatively, organizations may deflect attention from the problem to other related issues. For example, organizations criticized for using sweatshop labor in developing countries may emphasize their environmental credentials or their charitable projects. This entails influencing audience perceptions of the norm-appropriateness of the organization and its policies and procedures as congruent with industry norms or social values and beliefs (e.g., socially and environmentally responsible, concerned about employee welfare). Similarly, William Benoit proposes a variety of verbal remedial strategies used by firms to restore image in crisis situations. They are either aimed at rejecting or reducing organizational responsibility for the wrongdoing (denial and evasion of responsibility) or at reducing the offensiveness of the act of wrongdoing attributed to the organization (promising to correct the problem). Finally, organizations may try to restore image by asking forgiveness (mortification).

When organizations are affected by a controversial issue (e.g., minimum wage, redundancies, plant closure) or engage in structural reorganization (e.g., merger, privatization), they use language, such as rhetorical strategies, metaphors, and stories that resonate with cultural norms and beliefs, to influence audience perceptions. For example, organizations may use the rhetorical strategy of logos (appeal to logic) to portray the closure of a factory as necessary and thus legitimate. 


\section{Impression Management and Organizational Reputation}

Reputation is concerned with the relatively enduring respect or admiration in which an organization is held by multiple external audiences. It involves a comparison of how an organization's creditworthiness, its CSR, or its products or services compare to those of its competitors. Reputation not only resides in the mind of organizational audiences, but is also reflected in a variety of rankings, e.g., credit ratings (credit scores assigned by ratings agencies, such as Moody's, Standard and Poor, Fitch), environmental performance scores (Environmental, Social and Governance disclosure score, and various reputation scores (e.g., Forbes), including university rankings.

Organizations engage in impression management to influence audiences’ perceptions of the desirability and esteem of the organization. Alternatively, organizations use public communications, such as annual reports or CSR reports to directly influence rankings. This is particularly the case for CSR reports, which are used to portray organizations as continuously striving for sustainability.

Doris Maria Merkl-Davies

\section{FURTHER READINGS}

Benoit, W. L. (1997). Image repair discourse and crisis communications. Public Relations Review, 23(2), 177-186.

Brennan, N. M. \& Merkl-Davies, D. M. (2013). Accounting Narratives and Impression management. In L. Jackson, Davison, J., \& Craig, R. (Ed.), Routledge Companion to Communication in Accounting (109-132). Milton Park: Routledge.

Elsbach, K. D. (2003). Organizational perception management. Research in Organizational Behavior, 25, 297-332.

Goffman, E. (1959). The Presentation of Self in Everyday Life. New York: Doubleday Anchor Books.

Highhouse, S., Brooks, M.E. and Gregarus, G. (2009). An organizational impression management perspective on the formation of corporate reputations. Journal of Management, 35(6), 1481-1493. 
Illia, L., Sonpar, K. \& Bantimaroudis, P. (2014). Framing impressions in corporate communication. In J. Pallas, Strannegård, L. \& Jonsson, S. (Ed.). Organizations and the Media: Organizing in a Mediatized World (192-204). Milton Park: Routledge.

Merkl-Davies, D.M. \& Brennan, N. M. (2011). A Conceptual Framework of Impression Management: New insights from psychology, sociology, and critical perspectives. Accounting and Business Research, 41(5), 415-437. 